\title{
Pre-service teacher's ability in solving mathematics problems viewed from Self-Resilience
}

Dede Salim Nahdi*, Mohamad Gilar Jatisunda, \& Vici Suciawati

Universitas Majalengka, Majalengka, Indonesia, 45418

*Corresponding author: salimnahdi@unma.ac.id | Phone Number: +6285224977367

\section{ARTICLE INFO}

Received: 22-07-2021

Received in revised: 20-08-2021

Accepted: 17-09-2021

Available online: $30-10-2021$

\section{KEYWORDS}

Mathematical Problem Solving; Self-Resilience;

Problem based learning;

\section{A B S T R A C T}

The problem-solving ability is still a big problem for students. Many studies show that Indonesian students are still low in solving math problems. One thing that is needed in solving problems is selfresilience, so that students have resilience in facing problems. This study aims to analyze the differences in problem-solving abilities of pre-service elementary school teacher in terms of selfresilience. This study used a Quasi-Experiment method with the type Nonequivalent Pretest-Posttest Control Group. The population of this study were all elementary school teacher candidates at Majalengka University with a sample of 60 respondent. This study resulted in a significant difference in the increase in problem-solving abilities of student-teacher candidates. Based on Self Resilience, the group of students who received Problem Based Learning had higher problem-solving abilities than the group of students who received expository learning. Mathematical problem-solving ability requires students to have self-resilience because in solving problems, a person needs to have confidence in his ability to face problems.

\section{INTRODUCTION}

Mathematics plays a primary role in our daily lives (Dahia, 2010)(Mumcu, 2018). Humans can never be isolated from mathematics in the activities of life (Nahdi et al., 2020). Mathematics reveals hidden patterns that help us to understand the world around us (Roohi, 2012). Mathematics is a universal science that becomes the foundation for the development of science and technology and plays a role in advancing human thinking. In learning mathematics, someone is doing mental activities to be able to understand the meaning and relationship and symbols to be applied in real life (Herlina et al., 2012). These activities include understanding the problems at hand, determining how to use mathematics as a solution to problems, and making decisions. The experienced that is often the difficulty is how to apply mathematics in real life. This ability to solve problems.

According Bishop \& Polya (1991) in solving a problem, several stages must be passed, including (1) Understanding the problem; (2) Planning a settlement strategy; (3) Carry out the settlement; (4) Review the results obtained. These four stages are a related link. When students have difficulty at one stage, it will be challenging to carry out the next stage. Problem Solving has considered as an essential aspect of education (Rott, 2020). Problem-solving ability is the main goal in learning mathematics (Wilson et al., 2011). Problem-solving abilities are related to the student's ability to understand verbal sentences in problems, convert them into mathematical models, make calculation plans from mathematical models, and use numeracy skills to solve non-routine problems (Anisa, 2014). Implementation problem in this research like (Schoenfeld, 1992) the sense of working on non-routine problems.

In daily life consciously or unconsciously, every day, we are faced with various problems that require problemsolving abilities (Utami, 2017). By teaching problemsolving skills, students can develop and apply their mathematical abilities in dealing with problems in real life (Gurat, 2018). The ability to solve problems is something special because it is different from other thinking abilities and is a combination of several abilities (Rajendran, 2008; Harsela \& Asih, 2020). To improve problem-solving skills, several strategies that can be taught to students include 
analogy, guess-check revised, problem reformulation, solution drawing, systematic experimentation, way back and use of graphs of functions (Novotná, Jarmila et al., 2012).

The ability to solve mathematical problems is still a problem for most students, be it at the levels of primary education, secondary education and even higher education. In tertiary institutions, students still have difficulties when faced with non-routine math problems. This situation occurs in students of the PGSD Department of Majalengka University, most of whom lack a background in mathematics skills when taking secondary education. The inability of students to face problems causes students to have difficulty and phobia towards mathematics which ultimately results in low mathematics results and achievement.

The main output of the PGSD Department at Majalengka University is to produce teachers who master the substance of the material in-depth and teach it back okay. So to achieve this, students are required to be proficient in solving non-routine mathematical problems. Teaching math problem solving is a challenge for teachers. Mathematical problem solving continues to be a challenge for many teachers to teach effectively and students to learn proficiently (Chapman, 2016). As a result, teaching mathematical problem solving requires in-depth knowledge of the substance of the material. There are very rational difficulties in studying and understanding mathematics because mathematics is a lesson that requires learners to think critically, systematically and reflectively and requires vigilant, detailed and earnest effort (Hutauruk et al., 2019). Teaching for mathematical problem solving is incredibly challenging, for example, by requiring special knowledge (Ponte, 2001). Based on the results of research on problem-solving abilities, (Saadati et al., 2019), the large majority of students $(51.5 \%)$ failed to reach adequate "levels of proficiency" (they attained level 1 or below) in mathematics and problem solving, this weakness among students might be related to a scarcity of appropriate problem-solving activities in their mathematics lessons. It is essential for teachers to have good problem-solving skills as a provision for them to teach again.

Learning mathematics includes not only the "polished products" of mathematical activity, but also the understanding of implicit motivations, the sensemaking actions and the reflective processes of mathematicians, which aim to the construction of meaning (Clark et al., 2016). Not only cognitive abilities that can have achieved from mathematical activities, noncognitive factors are also another goal that must have achieved. Based on the results of the interview, it has identified that one of the problems for students was math anxiety. Mathematics anxiety is a noncognitive factor. Mathematical anxiety causes students to experience tense and anxious feelings that affect them when solving math problems, both in academic and real life. Mathematical resilience is one of the factors that have a role in supporting student achievement. Students who have perseverance have more chance to succeed than students who are lazy (Attami et al., 2020). On that basis, a student needs to have the ability to cope with, and improve himself from the math anxiety faced. Students need to have selfresilience to be able to survive the problems they face. Having an excellent self-resilience ability will lead to different beliefs towards mathematics, Young-Loveridge (2009) investigated how pre-service teachers' attitudes towards teaching mathematics may be different from attitudes towards mathematics.

It is a requirement that students have self-resilience so that they can provide reasonable confidence in mathematics as an interest for students to teach mathematics again. Lomas et al. (2012) beliefs are positions held by individuals that they feel to be accurate and their nature cannot be directly observed but must have inferred from actions. Self-resilience is the ability to use all internal and external resources to solve problems even though the problems at hand are complicated (Egeland et al., 2017). Resilience is described as competence in the face of adversity (Hamill, 2003) and as a set of qualities that help a person to withstand many of the negative effects of adversity (Gilligan, 2001). Self-resilience can overcome setbacks, challenges, and difficulties that are part of everyday academic life (Martin, 2013; Cassidy, 2015). Students who have Self-resilience are able to adapt to any changes, disturbances, or difficulties while maintaining good functional capacity (Lloyd et al., 2016; Hayward et al., 2010). Resilience describes a set of qualities that drive the successful process of adaptation and transformation despite the risks and hardship (Ariyanto et al., 2017). Lee \& Johnston-Wilder (2017) defined resilience as' a positive adaptive stance to mathematics such that it will allow them (pupils) to continue learning despite barriers and difficulties.

Increasing self-resilience is an essential task because it can provide experience for students in facing problems and challenges in learning mathematics. By increasing selfresilience, students can develop skills such as how to communicate, natural abilities in making settlement plans and being able to take the right steps for the problems at hand (Rojas F., 2015). They will try to find ways to turn stressful situations into opportunities for selfimprovement. The ability of self-resilience can eliminate the adverse effects of stress, increase the ability to adapt and develop problem-solving skills to deal with all forms of change and difficulty. Individuals who have self-resilience can choose to rise from all difficulties and challenges, by increasing their knowledge to be able to be adaptive and to overcome similar adverse situations in the future (Keye \& Pidgeon, 2013). Characteristics of humans who have high 
self-resilience tend to be easygoing and easy to socialize, have good thinking skills (traditionally called intelligence, which also includes social skills and the ability to judge things), believe in themselves and believe in their ability to make decisions and have spirituality or religiosity (Murphey et al., 2013)

In solving problems, the first step that students must take is to understand the problems they are facing correctly. Students who have self-resilience will quickly understand the problem because of their ability to adapt to the problems at hand. He will try to increase his potential to be able to find and identify information and data on problems that may need in solving math problems. Students with mathematical resilience possess a growth belief related to their abilities (Goodall \& Johnston-Wilder, 2015). The development of mathematical resilience can be affected and supported with coaching (Johnston-Wilder et al., 2013). Likewise, when making a strategic plan for completion and implementing it, self-resilience will support the process. Many studies have also reported that selfresistance has a profound effect on math abilities, including math problem-solving abilities (Maharani \& Bernard, 2018; Rokhmah et al., 2019; Attami et al., 2020; Rohmah et al., 2020)

Another effort to improve problem-solving skills is to determine a learning model that is relevant to the teaching material. This learning model must help students construct their knowledge in order to be able to solve real-life problems so that their problem-solving skills and activities match what expected in the learning objectives. The learning model that was following the above characteristics and thought to foster problem-solving abilities is the Problem Based Learning model (Arends, 2012). Problem Based Learning is a learning model characterized by the use of problems that exist in the real world to train students to think critically and to be skilled at solving problems, and to gain knowledge of essential concepts from what is learned (Duch, 1996). The series of learning activities in the Problem Based Learning model emphasizes the process of solving problems faced scientifically (Astuti, 2019). In problem-based learning, learning begins with students given contextual problems that are relevant to the teaching material to be delivered. It aims to motivate students for the learning that is carried out (Michael, 2004). The essence of the problems raised in Problem Based Learning is the gap between the real situation and the expected situation, or between what happens with expectations. This learning model can stimulate students' ability to think creatively, analytically, systematically, and logically in finding alternative problem-solving through empirical data exploration in order to foster scientific attitudes.

\section{METHOD}

This study used a Quasi-Experiment method with a posttest-only control group design. In this research design, the experimental group obtained learning with the Problem Based Learning model, and the control group used the expository learning model. Table 1 displays the research design.

Table 1.Research Design

\begin{tabular}{cccc}
\hline \multirow{2}{*}{ Learning model } & \multicolumn{3}{c}{ Level Self Resilience } \\
\cline { 2 - 4 } & High (S1) & Moderate (S2) & Low (S3) \\
\hline PBL (M1) & M1S1 & M1S2 & M1S3 \\
\hline Eks. (M2) & M2S1 & M2S2 & M2S3 \\
\hline
\end{tabular}

\section{Information:}

Si : Students who have self-resilience at level $\mathrm{i}$, for $\mathrm{i}=$ $1,2,3)$ with 1 = high, 2 = moderate, 3 = low

Mi : Students who get the $\mathrm{j}$-th learning model, for $\mathrm{j}=1,2$ with $1=\mathrm{PBL}, 2=\mathrm{Ex}$.

MiSi : Students who get the jth model and have selfresilience level $\mathrm{i}$.

The population of this study were all elementary school teacher candidates at Majalengka University, with a sample of 60 respondent who were selected by purposive sampling technique. Data collection techniques in this study were tests and questionnaires. The test used to collect data on math problem-solving abilities; questionnaires used to collect student self-resilience data. The instruments used in this study were descriptive tests and self-resilience questionnaires to distinguish high, medium and low selfresilience. The data analysis technique in this study used two-way ANOVA to test the hypothesis.

\section{RESULTS AND DISCUSSION}

The data from this study obtained from the test scores of problem-solving abilities by giving questions before and after being given treatment (pretest \& posttest). Problemsolving ability test designed use contextual problems to measure students' ability to solve non-routine problems.

Based on the results of data processing on the test scores of mathematical problem-solving abilities, the minimum, maximum, average score and standard deviation obtained in Table 2.

Table 2. Results of the test of mathematical problemsolving abilities

\begin{tabular}{cccccc}
\hline Group & N & Min & Max & Mean & Std. Dev. \\
\hline Experiment & 30 & 68 & 92 & 81.00 & 5.71 \\
\hline Control & 30 & 68 & 88 & 77.87 & 5.15 \\
\hline
\end{tabular}

Based on the table above, for the mathematical problem-solving ability, it can be seen the comparison of the results of the mathematical problem-solving ability test between the experimental class and the control class. The 
average value of the experimental class using the problembased learning model is 81.00 better than expository learning, which is an average value of 77.87. From the average final score of these students, it can concluded that descriptively the students' mathematical problem-solving abilities in the experimental class are better than the control class. The next step, students in both classes are distributed based on the level of self-resilience (high, medium, low). There is also a self-resilience level distribution technique using Table 3.

Table 3. N-gain criteria

\begin{tabular}{cc}
\hline $\mathrm{N}$-gain $(\mathrm{g})$ & Classification \\
\hline $\mathrm{g} \geq 0.70$ & High \\
\hline $0.30 \leq \mathrm{g}<0 / 70$ & Medium \\
\hline $\mathrm{g}<0.30$ & Low \\
\hline
\end{tabular}

Based on the results of the self-resilience questionnaire, students are grouped based on the level of self-resilience at Table 4.

Table 4. Self-Resilience qualification results

\begin{tabular}{cccc}
\hline \multirow{2}{*}{ Level self Resilience } & \multicolumn{2}{c}{ Group } & \multirow{2}{*}{ Total } \\
\cline { 2 - 3 } & Experimen & Control & \\
\hline High & 7 & 6 & 13 \\
\hline Medium & 18 & 16 & 34 \\
\hline Low & 5 & 8 & 13 \\
\hline Total & 30 & 30 & 60 \\
\hline
\end{tabular}

The results of mathematical problem-solving abilities test, both based on the level of self-resilience and as a whole, are descriptively presented in the Table 5.

Table 5. Results of tests for math problem solving abilities based on the level of self-resilience

\begin{tabular}{ccccc}
\hline Learning Model & Self & Mean & Std. Dev. & $\mathrm{N}$ \\
\hline \multirow{3}{*}{$\begin{array}{c}\text { Problem Based } \\
\text { Learning }\end{array}$} & High & 88.8571 & 2.41030 & 7 \\
\cline { 2 - 5 } & Medium & 79.7222 & 3.26849 & 18 \\
\cline { 2 - 5 } & Low & 74.6000 & 3.91152 & 5 \\
\cline { 2 - 5 } & Total & 81.0000 & 5.70541 & 30 \\
\hline \multirow{3}{*}{ Expository } & High & 81.6667 & 3.44480 & 6 \\
\cline { 2 - 5 } & Medium & 78.9375 & 3.51129 & 16 \\
\cline { 2 - 5 } & Low & 72.8750 & 5.61726 & 8 \\
\hline \multirow{3}{*}{ Total } & Total & 77.8667 & 5.15105 & 30 \\
\cline { 2 - 5 } & High & 85.5385 & 4.66575 & 13 \\
\cline { 2 - 5 } & Medium & 79.3529 & 3.35643 & 34 \\
\cline { 2 - 5 } & Low & 73.5385 & 4.92638 & 13 \\
\cline { 2 - 4 } & Total & 79.4333 & 5.61586 & 60 \\
\hline
\end{tabular}

From the table of the results of the test of mathematical problem-solving abilities above, students with a high level of self-resilience and obtaining a problem-based learning model obtained the highest average test result compared to other groups.

The results of data processing through two-way analysis of variance presented in the following Table 6.
Table 6. Analysis of Varian

\begin{tabular}{lccccc}
\hline \multicolumn{1}{c}{ Source } & $\begin{array}{c}\text { Type III Sum of } \\
\text { Squares }\end{array}$ & $\mathrm{df}$ & $\begin{array}{c}\text { Mean } \\
\text { Square }\end{array}$ & $\mathrm{F}$ & Sig. \\
\hline Model & 125.028 & 1 & 125.028 & 9.089 & .004 \\
\hline Self & 838.631 & 2 & 419.316 & 30.483 & .000 \\
\hline Model $^{*}$ Self & 97.639 & 2 & 48.820 & 3.549 & .036 \\
\hline
\end{tabular}

Based on the Table 6, through the probability technique, for students' mathematical problem-solving abilities in both experimental and control classes, a p-value (sig) of $0.004<0.05$ obtained, so $\mathrm{H}_{0}$ was rejected so that there was a difference in mathematical problem-solving abilities between students who obtained the Problem Based Learning (PBL) model and students. Who gets expository. Thus, the application of the PBL model, when compared to the expository module, is better at improving mathematical problem-solving abilities. Through the probability technique, for the mathematical problem-solving abilities of students with high, medium, and low self-resilience, a pvalue ( $\mathrm{sig}$ ) of $0.000<0.05$ obtained, so $\mathrm{H}_{0}$ is rejected so that there are differences in problem-solving abilities between groups of students who have high, moderate, and high selfresilience. And low. Based on the results of calculating descriptive statistics for each group, the average score of the problem-solving ability of students who have high selfresilience is better than students who have moderate and low self-resilience. Thus, high self-resilience has a significant effect on students' problem-solving abilities compared to moderate and low self-resilience.

To see the interaction between the learning model and students' self-resilience on their mathematical problemsolving abilities, the p-value (sig) is $0.036<0.05$, so $\mathrm{H}_{0}$ is rejected. Thus, it can be concluded that there is an interaction between the applied learning model and student-teacher student self-resilience on their mathematical problem-solving abilities. The interaction means that the learning model and self-resilience together have a significant influence on mathematical problemsolving abilities. In other words, the learning model has a different effect on the ability to solve mathematical problems if it applied to students who have different selfresilience.

Based on the results of the calculation of the two-way analysis of variance with different cell sizes, it concluded that there is an interaction between the applied learning model and students' self-resilience on their mathematical problem-solving abilities. Thus, because of the interaction between the two variables, it is followed by the Scheffe test to see the differences between groups of students who get the Problem Based Learning model and groups who get an expository model based on high, medium, and low selfresilience. 
The results of the Scheffe test calculations presented in Table 7.

Table 7. Scheffe Test

\begin{tabular}{ccccc}
\hline \multirow{2}{*}{ (I) self } & (J) self & $\begin{array}{c}\text { Mean Difference } \\
(\mathrm{I}-\mathrm{J})\end{array}$ & $\begin{array}{c}\text { Std. } \\
\text { Error }\end{array}$ & Sig. \\
\hline \multirow{2}{*}{ High } & Medium & $6.1855^{*}$ & 1.20943 & .000 \\
\cline { 2 - 5 } & Low & $12.0000^{*}$ & 1.45474 & .000 \\
\hline \multirow{2}{*}{ Medium } & High & $-6.1855^{*}$ & 1.20943 & .000 \\
\cline { 2 - 5 } & Low & $5.8145^{*}$ & 1.20943 & .000 \\
\hline \multirow{2}{*}{ Low } & High & $-12.0000^{*}$ & 1.45474 & .000 \\
\cline { 2 - 5 } & Medium & $-5.8145^{*}$ & 1.20943 & .000 \\
\hline
\end{tabular}

Based on the results of the Scheffe test (table 7), for comparisons between groups of students based on the level of self-resilience and learning models all have a p-value (sig) of $0.000<0.05, \mathrm{H}_{0}$ is rejected. Thus, the problemsolving ability of students who have high, medium, and low levels of self-resilience for each of the learning models used is significantly different. The average score of students' problem-solving abilities with high self-resilience and using a problem-based learning model is the highest compared to other groups of students. Thus, the problem-solving abilities of students who have high self-resilience and obtain a problem-based learning model are better than other groups of students.

This is well understood because self-resilience is very supportive of problem-solving abilities. People who have high self-resilience will try to increase their potential so that they can adjust to the problems at hand. He does not see problems as burdens but instead sees them as a platform to develop himself. Besides, the problem-based learning model is also able to provide facilities for students to improve their problem-solving abilities. With this learning model, students given contextual math problems to solve. This method requires them to develop their thinking skills to be able to use mathematics as a medium for solving. They will be familiar with life's problems that can be solved utilizing mathematics.

\section{CONCLUSION}

Based on the research results, several conclusions obtained, including: 1). The problem-solving ability of elementary school teacher candidate students who obtained the Problem Based Learning (PBL) model was better than students who obtained the Expository Learning model. 2). There are differences in mathematical problemsolving abilities between groups of students who have high, medium, and low self-resilience. High Self Resilience has a better effect on mathematical problem-solving abilities than moderate and low Self Resilience. 3). There is an interaction between the applied learning model and student-teacher student self-resilience on their mathematical problem-solving abilities.
The problem-solving ability of students who have high selfresilience and obtain a problem-based learning model is better than other groups of students.

\section{Acknowledgements}

Researchers would like to thank Universitas Majalengka for providing opportunities, facilities and support so that the writing of this article is complete.

\section{REFERENCES}

Anisa, W. (2014). Peningkatan Kemampuan Pemecahan Masalah dan Komunikasi Matematik melalui Pembelajaran Pendidikan Matematika Realistik untuk Siswa SMP Negeri di Kabupaten Garut. Jurnal Pendidikan Dan Keguruan, 1(1), 209668.

Arends, R. (2012). Learning To Teach. Central Connecticut State University.

Ariyanto, L., Herman, T., Sumarmo, U., \& Suryadi, D. (2017). Developing Mathematical Resilience of Prospective Math Teachers. Journal of Physics: Conference Series, 895(1). https://doi.org/10.1088/1742-6596/895/1/012062

Astuti, T. P. (2019). Model Problem Based Learning dengan Mind Mapping dalam Pembelajaran IPA Abad 21. Proceeding of Biology Education, 3(1), 64-73.

https://doi.org/10.21009/pbe.3-1.9

Attami, D., Budiyono, B., \& Indriati, D. (2020). The mathematical problem-solving ability of junior high school students based on their mathematical resilience. Journal of Physics: Conference Series, 1469, 012152. https://doi.org/10.1088/1742-6596/1469/1/012152

Bishop, C., \& Polya, G. (1991). How to Solve It. The Mathematical Gazette. https://doi.org/10.2307/3619013

Cassidy, S. (2015). Resilience building in students: The role of academic self-efficacy. Frontiers in Psychology, 6(NOV), 114. https://doi.org/10.3389/fpsyg.2015.01781

Chapman, O. (2016). An exemplary mathematics teacher's way of holding problem-solving knowledge for teaching. Proceedings of the 40th Conference of the International Group for the Psychology of Mathematics Education, 139146.

Clark, K., Kjeldsen, T., Schorcht, S., Tzanakis, C., Clark, K., Kjeldsen, T., Schorcht, S., Tzanakis, C., \& Wang, X. (2016). History of mathematics in mathematics education . Recent developments. In History and Pedagogy of Mathematics.

Dahia, vijay. (2010). Why Study Mathematics? Applications of Mathematics in Our Daily Life. Mathematical Applications and Modelling, 1(10), 151-177.

https://doi.org/10.1142/9789814313353_0009

Duch, B. (1996). Problems: A key factor in PBL. About Teaching, $50,7-8$.

Egeland, B., Carlson, E., \& Sroufe, A. L. (2017). Resilience as process. Development and Psychopathology, 5(4), 517-528.

Gilligan, R. (2001). Promoting Resilience. A resource guide on working whith children in the care system. In Britsh Agencies for adoption and Fostering. 
Goodall, J., \& Johnston-Wilder, S. (2015). Overcoming Mathematical Helplessness and Developing Mathematical Resilience in Parents: An Illustrative Case Study. Creative Education, 06(05), 526-535.

https://doi.org/10.4236/ce.2015.65052

Gurat, M. G. (2018). Mathematical problem-solving strategies among student teachers. Journal on Efficiency and Responsibility in Education and Science, 11(3), 53-64. https://doi.org/10.7160/eriesj.2018.110302

Hamill, S. K. (2003). Resilience and Self-Efficacy: The Importance of Efficacy Beliefs and Coping Mechanisms in Resilient Adolescents. Colgate University Journal of the Sciences, 115-146.

Harsela, K., \& Asih, E. C. M. (2020). The level of mathematical resilience and mathematical problem-solving abilities of 11 th grade sciences students in a senior high school. Journal of Physics: Conference Series, 1521, 032053. https://doi.org/10.1088/1742-6596/1521/3/032053

Hayward, M. L. A., Forster, W. R., Sarasvathy, S. D., \& Fredrickson, B. L. (2010). Beyond hubris: How highly confident entrepreneurs rebound to venture again. Journal of Business Venturing, 25(6), 569-578. https://doi.org/10.1016/j.jbusvent.2009.03.002

Herlina, S., Turmudi, M., \& Dahlan, J. A. (2012). Efektivitas Strategi React Dalam Upaya Peningkatan Kemampuan Komunikasi Matematis Siswa Sekolah Menengah Pertama. Jurnal Pengajaran MIPA, 12(1), 1-7.

Hutauruk, A. J., Darmayasa, J. B., \& Priatna, N. (2019). Achievement of students mathematical resilience through problem based learning model with metacognitive approach. Journal of Physics: Conference Series, 1315, 012051. https://doi.org/10.1088/1742-6596/1315/1/012051

Johnston-Wilder, S., Lee, C., Garton, L., Goodlad, S., \& Brindley, J. (2013). Developing Coaches for Mathematical Resilience. ICERI 2013: 6th International Conference on Education, Research and Innovation. https://doi.org/10.5860/choice.512973

Keye, M. D., \& Pidgeon, A. M. (2013). Investigation of the Relationship between Resilience, Mindfulness, and Academic Self-Efficacy. Open Journal of Social Sciences, 01(06), 1-4. https://doi.org/10.4236/jss.2013.16001

Lee, C., \& Johnston-Wilder, S. (2017). The Construct of Mathematical Resilience. In Understanding Emotions in Mathematical Thinking and Learning (pp. 269-291). Elsevier. https://doi.org/10.1016/B978-0-12-802218-4.00010-8

Lloyd, K. D., Katz, A. S., \& Pronk, N. P. (2016). Building Emotional Resilience at the Workplace. ACSM's Health \& Fitness Journal, 20(1), 42-46. https://doi.org/10.1249/FIT.0000000000000170

Lomas, G., Grootenboer, P., \& Attard, C. (2012). The affective domain and mathematics education. Research in Mathematics Education in Australasia 2008-2011, 9789460919701, 23-37. https://doi.org/10.1007/978-946091-970-1_3

Maharani, S., \& Bernard, M. (2018). Analisis Hubungan Resiliensi Matematik Terhadap Kemampuan Pemecahan Masalah Siswa Pada Materi Lingkaran. JPMI (Jurnal Pembelajaran
Matematika Inovatif), 1(5), 819.

https://doi.org/10.22460/jpmi.v1i5.p819-826

Martin, A. J. (2013). Academic buoyancy and academic resilience: Exploring 'everyday' and 'classic' resilience in the face of academic adversity. School Psychology International, 34(5), 488-500. https://doi.org/10.1177/0143034312472759

Michael, P. (2004). Does Active Learning Work ? A Review of the Research. Journal of Engineering Education, 93(July), 223231.

Mumcu, H. Y. (2018). Examining Mathematics Department Students' Views on the Use of Mathematics in Daily Life. International Online Journal of Education and Teaching (IOJET), 5(1), 61-80.

Murphey, D., Barry, M., \& Vaughn, B. (2013). Positive Mental Health. Positive Mental Health Resilience. https://www.sprc.org/resources-programs/positive-mentalhealth-resilience

Nahdi, D. S., Jatisunda, M. G., Cahyaningsih, U., \& Suciawati, V. (2020). Pre-service teacher's ability in solving mathematics problem viewed from numeracy literacy skills. Elementary Education Online, 19(4), 1902-1910. https://doi.org/10.17051/ilkonline.2020.762541

Novotná, Jarmila, Eisenmann, P., Přibyl, J., Ondrušová, J., \& Břehovský, J. (2012). Problem Solving in School Mathematics Based on. Journal on Efficiency and Responsibility in Education and Science, 7(1), 1-6. https://doi.org/10.7160/eriesj.2013.070101

Ponte, J. P. D. A. (2001). Investigating Mathematics and Learning To Teach Mathematics. Making Sense of Mathematics Teacher Education, 2001, 53-72.

Rajendran, N. S. (2008). Teaching \& acquiring higher-order thinking skills: Theory \& practice. Universiti Pendidikan Sultan Idris.

Rohmah, S., Kusmayadi, T. A., \& Fitriana, L. (2020). Mathematical connections ability of junior high school students viewed from mathematical resilience. Journal of Physics: Conference Series, 1538, 012106. https://doi.org/10.1088/1742-6596/1538/1/012106

Rojas F., L. F. (2015). Factors Affecting Academic Resilience in Middle School Students: A Case Study. GiST Education and Learning Research Journal, 11(11), 63-78. https://doi.org/10.26817/16925777.286

Rokhmah, K. N., Retnawati, H., \& Solekhah, P. (2019). Mathematical resilience: Is that affecting the students' mathematics achievement? Journal of Physics: Conference Series, 1320, 012036. https://doi.org/10.1088/17426596/1320/1/012036

Roohi, F. (2012). Role of Mathematics in the Development of Society. National Meet on Celebration of National Year of Mathematics, 1-14. http://www.ncert.nic.in/pdf_files/FinalArticle-Role of Mathematics in the Development ofSociety-NCER.pdf

Rott, B. (2020). Teachers' Behaviors, Epistemological Beliefs, and Their Interplay in Lessons on the Topic of Problem Solving. International Journal of Science and Mathematics Education, 18(5), 903-924. https://doi.org/10.1007/s10763019-09993-0 
Saadati, F., Cerda, G., Giaconi, V., Reyes, C., \& Felmer, P. (2019). Modeling Chilean Mathematics Teachers' Instructional Beliefs on Problem Solving Practices. International Journal of Science and Mathematics Education, 17(5), 1009-1029. https://doi.org/10.1007/s10763-018-9897-8

Schoenfeld, A. H. (1992). Learning To Think Mathematically : Sense-Makingin Mathematics. In Handbook for research on mathematics teaching and learning (pp. 334-370). MacMillan.
Utami, C. T. (2017). Self-Efficacy dan Resiliensi: Sebuah Tinjauan Meta-Analisis. Buletin Psikologi, 25(1), 54-65.

https://doi.org/10.22146/buletinpsikologi.18419

Wilson, J. W., Fernandez, M. L., \& Hadaway, N. (2011). Mathematical Problem Solving. The University of Georgia. http://jwilson.coe.uga.edu/emt725/PSsyn/Pssyn.html

Young-Loveridge, J. (2009). Two Decades of Mathematics Education Reform in New Zealand: What Impact on the Attitudes of Teacher Education Students? Shaping the Future of Mathematics Education: Proceedings of the 33rd Annual Conference of the Mathematics Education Research Group of Australasia, 705-712. 